Derecho y Realidad

Núm. 22 • II semestre de 2013

Facultad de Derecho y Ciencias Sociales, UPTC

ISSN: 1692-3936

\title{
Influencia de la religión en la política y su posición respecto a la configuración de la oposición política en Colombia
}

\author{
Influence of religion in politics and its position with \\ regard to the configuration of political opposition in \\ Colombia
}

Iván Camilo Saavedra Buitrago*

\section{Resumen}

Este escrito presenta un acucioso aunque breve relato acerca de la manera como la historia política de Latinoamérica y en especial la colombiana, ha estado siempre marcada por acontecimientos en los que la religión o, concretamente, los representantes de dichas organizaciones han intervenido en asuntos sociales que posteriormente se traducen en manifestaciones políticas. Las cuales, muchas veces, influyen en la administración del Estado, ya que estas no solo ostentan un poder moral-político, sino que usualmente se encuentran amparadas por el capital. Ello ocasiona que aquellas confesiones que no gocen de las cualidades anteriormente descritas, sean gravemente discriminadas por dichas organizaciones usando muchas veces el poder del Estado, mediante la acción u omisión de este para cumplir con su objetivo; esto es, desamparándolas jurídicamente, obligándolas a abandonar sus creencias, tradiciones y costumbres; en otras palabras, despojándolas de cualquier rasgo relacionado con su idiosincrasia e impidiendo, por

* Estudiante de Derecho y Ciencias sociales, Universidad Pedagógica y Tecnológica de Colombia, integrante del grupo de investigación Red Humana, semillero de investigación Rafael Uribe Uribe. Correo electrónico: ivancamilo.saavedra@uptc.com 
92 Derecho y Realidad

consiguiente, que el pueblo colombiano adquiera cultura política y obtenga un juicio crítico frente a la realidad social.

\title{
Palabras clave
}

religión, política, partidos políticos, Estado y capital.

\begin{abstract}
This paper presents a meticulous but brief report about how political history of Latin America and particularly the Colombian, has always been marked by events in which religion or, specifically, the representatives of these organizations have been involved in social affairs that subsequently translates into political demonstrations. Which, often, influence in the administration of the State, since they do not only hold a moral-political power, but usually are covered by the capital. This causes that those confessions that do not receive the described qualities, are seriously disadvantaged by such organizations using many times the power of the State, by action or omission to fulfill its objective; that is, to bequeath them legally, forcing them to abandon their beliefs, traditions and customs; in other words, stripping them of any trait related to their idiosyncrasies and therefore preventing the Colombian people to get political culture and a critical judgment against social reality.
\end{abstract}

\section{Key words}

religion, politics, political parties, State and capital. 
Antes de iniciar con la idea planteada anteriormente, se presentará una síntesis sobre las condiciones sociales, políticas, económicas y culturales de la España del siglo XV hasta la primera década del siglo XVIII, la cual consideramos que será la clave para entender todo lo relacionado con el fenómeno presentado desde la independencia del virreinato de la Nueva Granada hasta la actualidad.

En el siglo XV, España se encontraba dividida en reinos, producto de la reconquista que se había llevado a cabo desde el año 718 hasta 1492, donde se rindieron los últimos musulmanes situados en el reino de Granada con la ayuda constante de la Iglesia católica. Aunque España se había unificado territorialmente, no estaba políticamente consolidada, como solución al problema en 1479 contrae matrimonio Fernando II de Aragón e Isabel I de Castilla, pero esto no fue suficiente, debido a que las dos coronas mantenían su independencia y sus diferencias regionales. En el mismo año, España descubrió a América; “Ambos acontecimientos están marcados por el espíritu de cruzada, donde la Iglesia y el Estado se interpenetraban mutuamente. Las ideas de Cristiandad y de Cruzada contra los moros gozaban de apoyo popular, que se proyectaría luego a la Conquista de América" (González, 1997b, p. 28).

Pietschman opina que la Corona española tenía inicialmente una concepción de apostolado civilizador, que se iría secularizando hasta convertirse en una de las bases más importantes de la política colonial del Imperio español (citado por González, 1997b, p. 30). Lo anterior nos lleva a inferir que la religión, en este caso la católica, funciona no solo como modo de respuesta hacia los fenómenos naturales que suceden en nuestro medio, sino también como forma de cohesión social y política de un Estado, la cual le otorga la legitimidad para actuar muchas veces de manera despótica con el objeto de establecer y mantener la unidad nacional.

Tanto es así que "cuando se empiezan a consolidar los Estados nacionales y los soberanos tienden al absolutismo, la Corona [española] busca controlar más los nombramientos eclesiásticos, para lograr que el poder de la Iglesia estuviera bajo el servicio de la consolidación del Estado" (González, 1997b, p. 31). Posteriormente, en el reinado de Felipe II, se creó la denominada Junta Magna que tenía como objeto:

estructurar el patronato de manera que excluyera toda injerencia papal y fomentara la creación de una iglesia totalmente hispanizada en América. (...) prohibió la difusión de cualquier obra que exaltara los logros culturales de las sociedades aborígenes y que diera a conocer sus creencias y costumbres. Además, estableció la censura para las obras que hablaran de la conquista y de los conflictos entre la iglesia y Estado en América. Para estas medidas, se contaba con el apoyo de la Inquisición, implantada en Lima en 1569 y en México en 1570. (González, 1997b, p. 37). 
Se puede observar no solo una especie de simbiosis entre la monarquía española y la Iglesia Católica para conseguir sus fines, menoscabando a las comunidades indígenas su idiosincrasia a través de la violencia, sino también negándoles la posibilidad de darse a conocer ante el mundo y la imposibilidad de estos de saber la situación llevada entre estas dos instituciones. Como dijo Eduardo Galeano (1970, p. 25), "la epopeya de los españoles y los portugueses en América combinó la investigación de la fe cristiana en la usurpación y el saqueo de las riquezas nativas", tanto que "la espada y la cruz marchaban juntas en la conquista y en el despojo colonial” (Galeano, 1970, p. 35).

La interrelación entre el Estado español y la Iglesia llegó hasta tal punto que esta legitimó la conquista del Nuevo Mundo por medio del "poder divino" otorgado por Dios al papa Alejandro VI para donar las tierras descubiertas y evangelizar bajo la fe cristiana a los aborígenes considerados inferiores por sus condiciones sociales, religiosas, culturales y económicas.

Llegaron a considerar que mencionada actuación era una conquista justa ya que eran concebidos infieles al dogma cristiano. Juan Ginés de Sepúlveda, uno de los tantos defensores de esta postura, llegó a decir que "consideraba justa la guerra contra los indios y la encomienda, pues veía el sometimiento de los aborígenes como una condición fundamental para un intento de evangelización" (González, 1997b, p. 44 y ss.). Empero, no todos los discípulos del catolicismo estaban de acuerdo con ello, pues Bartolomé de Las Casas, Francisco de Vitoria, entre otros, decían que el uso de la violencia para la interiorización de la fe en la cultura de los indígenas no estaba legitimada, ya que ellos no debían ser considerados esclavos porque tenían su propia organización política, económica y religiosa en un estado primitivo; sin embargo, no desconocían la idea de que la Corona tenía un poder superior que aquellos y por tanto debían ser convertidos a la Cristiandad universal por medio del dialogo y la persuasión.

Como consecuencia de lo antedicho, en los territorios conquistados se empezó a dar un ambiente etnocentrista y discriminatorio, el cual condujo a "la segregación entre la república de los españoles y la república de los indios, creada para evitar los malos efectos del contacto entre españoles e indígenas, (...). La consideración de los aborígenes como menores de edad, necesitados de tutela paternal de clérigos y gobernantes, reforzaba igualmente esta desigualdad social" (González, 1997b, p. 55).

La relación entre Iglesia y Estado no solamente se traduce en la legitimación política de las acciones del segundo, como lo acabamos de ver, sino que esta íntima relación va más allá, y se traslada al campo de lo socioeconómico, tal como lo afirma Isidoro Moreno Navarro: 
Se refleja la función central de las ideologías religiosas como cemento cohesionador entre colectivos sociales relacionados de forma desigualitaria, al legitimar de forma extrasocietaria, por la existencia de un orden divino (...) válido para toda la eternidad, dichas relaciones sociales de dominación y el orden social que conllevan, prometiendo, a la vez, una vida eterna feliz a cuantos no cuestione en la terrenal el orden establecido por Dios-que es el orden social sacralizado-. El que como enseñan la mayor parte de religiones sistematizadas, los ricos tengan más dificultades para ganar el paraíso que los pobres fue, sin duda, un anuncio que ha contribuido a hacer más soportables para los oprimidos las injusticias en este mundo ante la promesa de que, en el otro, la igualdad y la justicia serian la norma. (Citado por Vladimir, 2002a, p. 41).

Esta reflexión puede constatarse para la época de la colonización española, tomando las palabras de Fernán González:

la Corona inicia una política metódica de separación residencial entre las razas y un sistema forzado de trabajo indígena, dirigido por el Estado, para abastecer de mano de obra a la economía colonial. Estas medidas obedecían a las ideas eclesiásticas sobre las condiciones óptimas para la evangelización y reeducación de los aborígenes, pero facilitaban también tanto la explotación económica como el control del Estado sobre los naturales. (Cursivas fuera de texto) (...) por ello, Pietsmann concluye que en la sociedad colonial americana se introdujeron a la vez principios de estratificación económica, resultantes de la Conquista y ocupación de la tierra junto con principios de clase social fomentados por el Estado y principios de gradación de una sociedad de castas apoyada en diferencias raciales, fundada ésta última en motivaciones religiosocivilizadoras. (1997b, p. 56)

Realizado este bosquejo general de la España conquistadora, de sus orígenes como Estado nación y de su colonización en el territorio iberoamericano con el auspicio de la Iglesia católica, podemos avanzar en lo concerniente a la historia colombiana desde la época de la colonización, la cual nos permitirá concebir una idea históricopolítica desde el proceso de independencia hasta nuestros días.

Desde el siglo XVI, el territorio de lo que actualmente es Colombia se encontraba colonizado por la Corona española, la cual otorgaba mucha libertad a la Iglesia católica que tenía facultades jurisdiccionales sobre asuntos civiles y eclesiásticos, lo que propició confrontaciones con la jurisdicción civil otorgada a la real audiencia por el Estado español. Durante el periodo de los reyes católicos: Isabel I de Castilla y Fernando II, Carlos V y Felipe II, había una confusión entre la jerarquía eclesiástica y la autoridad civil, a tal punto que la Iglesia tomaba atribuciones civiles, y la real audiencia, en materia eclesiástica. 
Cuando el poder monárquico pasa a manos de los Borbones, se crea el virreinato de la Nueva Granada, lo que significó el desvanecimiento del poder político por parte de la Iglesia, la cual fue instrumentalizada por el gobierno monárquico para consolidar la unidad del imperio mediante la legitimación del sistema de castas justificado desde la enseñanza formal de la religión a indígenas y esclavos, donde los misioneros profesaban la obediencia al amo y al rey, este último gozaba no solo de un poder temporal sino de un poder divino delegado por Dios, lo que contribuyó a la disminución de conflictos entre la religiosidad y el Estado, ya que a aquella solo le fueron encargados asuntos meramente eclesiásticos.

A pesar de esta situación, la jerarquía eclesiástica y las demás órdenes religiosas: dominicos, franciscanos, jesuitas, tenían el pleno control sobre la educación tanto básica como superior, donde el Estado solo apoyaba en recursos para que los particulares manejaran todo lo concerniente a la enseñanza. Por ejemplo, en 1654 se fundó el Colegio el Rosario por el arzobispo Cristóbal de Torres; en 1608 fue fundado el Colegio Santo Tomás, ambas instituciones creadas por dominicos, el Colegio San Bartolomé, el cual fue fundado por el arzobispo Bartolomé Loboguerrero, quien entregó su dirección a los jesuitas; estos últimos fundadores de la Universidad Javeriana. Los jesuitas y dominicos tenían confrontaciones fuertes sobre los privilegios de la Universidad Javeriana y la Universidad Santo Tomás.

Desde nuestro punto de vista, cuando el monopolio de la educación lo tenían las invariables organizaciones religiosas, la religión seguía teniendo gran influencia en la política del virreinato, porque era ella la que formaba a la burocracia del gobierno y, de esta manera, impedía que otras organizaciones, incluso el Estado, capacitaran a sus funcionarios, lo que ocasionaba que se siguiera por la misma línea ideológica de la sociedad neogranadina imposibilitando la formación de un pluralismo político y religioso.

Paralelamente a lo anterior, los grupos de religiosos, llámense dominicos, jesuitas, franciscanos, desde finales del siglo XVI empezaron a aprender el idioma de los indios para instruirlos posteriormente en la enseñanza de la religión católica, aunque muchos de los misioneros fueron a los diferentes pueblos aborígenes a evangelizarlos, estos aprendieron las doctrinas y dogmas cristianos que les fueron comunicados teniendo como referencia su contexto social y cultural, muchas veces tergiversando lo dicho por los misioneros, hasta el punto de que mencionados conocimientos transferidos de estos a aquellos fueron considerados idolatrías. Como respuesta a ello, se plantea una idea radical, la cual consiste en la enseñanza del idioma español a los niños indígenas, prohibiéndoles tanto a ellos como a los indios adultos hablar en su lenguaje nativo, lo que ocasionó el olvido de su lengua por la mayoría de las comunidades indígenas existentes. 
Cabe anotar que la evangelización de los pueblos aborígenes estaba intrínsecamente relacionada con la colonización del Estado monárquico, donde es actualmente Colombia, por tanto, no tuvo gran acogida la evangelización en los territorios del Urabá, Caquetá, Putumayo, donde no había una real presencia de las autoridades civiles.

Producto de todo lo anterior, la iglesia criolla adquiere un gran prestigio social, político y económico, tanto que "El Culto esplendoroso, con frecuentes fiestas religiosas, las misas solemnes con sermones grandilocuentes, la edificación de templos, el auge del arte religioso y la acumulación de riquezas a manos de la iglesia, nos muestran la importancia que ella adquiere en la sociedad colonial de esta centuria" (González, 1997b, p. 81 y 82).

Para inicios del siglo XVIII, la clase mestiza había aumentado tanto, que ya la Iglesia no podía sostener más el régimen de castas, pero sigue siendo un ente que defiende la discriminación racial y étnica, manteniendo el monopolio de la educación junto con los jesuitas, para las clases privilegiadas, negándole el acceso a aquellas personas que no fueran de sangre pura, no solo a lo estrictamente educativo sino también a cargos civiles y eclesiásticos; dando como consecuencia el ahondamiento de la segregación social presentada en ese entonces tanto a la clase mestiza, indígena y esclava.

Ahora se presentará una síntesis de lo relacionado con el proceso de independencia, no sin antes hacer mención de una cita de Fernán González que, desde el objeto aquí planteado, mostrará el entorno en el cual se va a desenvolver la política y la oposición política:

Esta situación traerá como consecuencia el hecho de que las regiones pobladas a partir del siglo XVIII van a ser muy reacias al control de la jerarquía eclesiástica, profundizando la diferenciación regional de la presencia de la iglesia católica, que está esencialmente ligada al proceso histórico y geográfico de la Conquista y la Colonización. Como hemos visto, desde los primeros días de la Conquista y la Colonia, la evangelización se concentró en las regiones más plenamente integradas al dominio español, donde la mayor densidad demográfica y más compleja organización social permitió el establecimiento de encomiendas, mitas, resguardos y haciendas. O sea, el altiplano cundiboyacense ("El Reino") y los altiplanos del suroccidente (Cauca y Nariño centrales). También hubo fuerte presencia de la iglesia de la sociedad criolla de las principales ciudades. La presencia de la Iglesia en las zonas no plenamente integradas a la Corona (Darién, Guajira, Llanos, Orinoquia y Amazonia) fue precaria, a pesar de algunos esfuerzos misioneros por parte de las comunidades religiosas. (1997b, p. 118). 
Con el grito de independencia de 1810, empezó el periodo mal denominado "La patria boba", durante el cual existió gran injerencia de los religiosos, tanto así que se dio el calificativo de "revolución clerical" por Jorge Tadeo Lozano. "Varios llegaron a tomar las armas y desempeñaron un papel muy importante en la [sic] guerrillas patrióticas como el cura de Manta, (...) el cura de Gachetá, (...) y el famoso dominicano Ignacio Mariño, guerrillero en los Llanos Orientales, cuya intervención en la decisión del paso de los Andes en la campaña libertadora fue decisiva (sic)" (González, 1997b, p. 130-131). No solo en 1810, los clérigos apoyaron la independencia de la Nueva Granada, que duró el tiempo necesario para alcanzar la independencia definitiva de la Corona española (1819), con el objetivo de conseguir la autonomía que tanto anhelaban para dejar de estar sumisos al gobierno civil mediante el patronato ${ }^{2}$.

Los primeros gobernantes de la recién nación independizada empezaron a detentar el poder que otorgaba el patronato al Estado español, como fórmula para mantener la cohesión social y política del país, mediante la instrumentalización de la religión para consolidar la unidad nacional, debido a que "los nuevos Estados carecían de plena legitimidad, sus rentas fiscales eran exiguas y su aparato administrativo era precario. En cambio, la iglesia disfrutaba de una sólida situación económica, de gran aceptación social (sobre todo entre las masas populares), y de suficiente clero para garantizar la presencia de la iglesia en los más apartados rincones de la nación" (González, 1997b, p. 140), lo que también motivó al Vaticano tras la reciente independencia de "establecer vínculos propios con las iglesias de las nuevas naciones hispanoamericanas”. (González, 1997b, p. 140).

Confirmando lo anterior, en 1824, estando Bolívar en el Perú y el vicepresidente Santander en ejercicio efectivo del mando, el Congreso declaró a la República de Colombia en posesión del antiguo patronato de Indias con todas sus prerrogativas. Sin embargo, los primeros conflictos se presentan en los gobiernos protoconservadores de Márquez (1837-1841) y de Herrán (1841-1845), en donde en 1840 se aprueba una ley que exige el pase del gobierno para divulgar bulas o rescriptos papales, y en 1841 se encarga por ley a los jefes de policía que vigilen a los prelados y curas para que no introduzcan novedades en la disciplina exterior de la Iglesia y que cuiden que no se usurpe el patronato, la soberanía y los privilegios de la República ni la autoridad del poder civil.

En el gobierno de Tomás Cipriano de Mosquera (1845-1849), quien fue ayudado en la campaña por su hermano el arzobispo Mosquera, propone un proyecto de ley

\footnotetext{
2 El patronato es una figura política-jurídica usada por los reyes de España acordado con la Santa Sede, en donde el primero tenía la potestad de nombrar arzobispos, obispos y demás privilegios relacionados por la jerarquía eclesiástica (conventos, educación etc.).
} 
ante el Congreso, el cual versaba sobre la expropiación de bienes en manos de la Iglesia, en donde arguye que "son una inmensa rémora para el progreso económico, un medio de opresión política y religiosa y una reliquia del ominoso feudalismo" (González, 1997b, p. 146), en esta ley, además de la desamortización de bienes de manos muertas por parte del clero, propuso la derogación del diezmo a cambio de un impuesto general para el sostenimiento del mismo que solo sería pagado por los que trabajan en la agricultura.

Así, se redactan en 1848 y 1849 los primeros programas de los partidos Conservador y Liberal que se contradistinguen con relación a la posición que asumen respecto al papel social y político de la iglesia y a la presencia de los jesuitas en el campo educativo. Pero este hecho no es fruto de una esencia o naturaleza ahistórica que llevaría a la iglesia a aliarse con el partido Conservador por representar los mismos intereses socioeconómicos (por ejemplo, los intereses de los terratenientes tradicionales), sino el resultado concreto de un proceso histórico, complejo y contradictorio, que se evidencia en las luchas políticas específicas en torno a los gobiernos de Márquez, Mosquera, José Hilario López, y Obando. (González, 1997a, p. 29).

Lo que permite inferir que los partidos políticos tradicionales (liberal y conservador) fueron fruto de la situación fáctica presentada en la primera mitad del siglo XIX respecto al papel de la Iglesia en la política, la cual se aleja de los postulados promulgados por Ezequiel Rojas fundador del partido liberal, con base en la candidatura de José Hilario López, quien arguye "quiere el partido liberal que no se adopte la religión como medio para gobernar" (González, 1997b, p. 150). Por su parte, el partido conservador en su primer programa, elaborado por Mariano Ospina Rodríguez y José Eusebio Caro, expresa como punto central: "el partido conservador es el que reconoce y sostiene... la moral del cristianismo y sus doctrinas civilizadoras contra la inmoralidad y las doctrinas corruptoras del materialismo y del ateísmo... la tolerancia real y efectiva contra el exclusivismo y la persecución, sea del católico contra el protestante y el deísta, o del ateísta contra el jesuita y el fraile" (González, 1997b, p. 150).

El distanciamiento de la Iglesia católica respecto del partido liberal tiene su primer origen en la llamada Guerra de los Supremos, la cual fue auspiciada principalmente por el obispo Moreno, obispo de la diócesis de Nariño, esta no fue solamente apoyada mediante el reclutamiento de personas a través de los confesionarios y la comunión, sino también mediante la financiación.

y sus consecuencias se hacen expresas en la reforma constitucional de 1843 y la reforma educativa de 1842: en ambas jugaría un importante papel el futuro ideológico conservador, Mariano Ospina Rodríguez. Los gobiernos 
protoconservadores de Márquez y de Herrán empiezan a adoptar medidas cada vez más favorables a la iglesia católica, en parte como contraprestación del apoyo de la jerarquía le había prestado (...) y en parte porque necesitaban una base social de apoyo que le permitiera contrarrestar las tendencias supuestamente anarquizantes de la educación y más o menos federalizantes de la Constitución de 1832. (González, 1997ª , p. 30)

Con las Constituciones de 1843 y 1858 que establecieron la separación de la Iglesia y el Estado como fórmula para acabar con el conflicto presentado entre estas instituciones, tanto así que el general Mosquera, al terminar el periodo presidencial (1845-1849), propuso ante el Congreso la derogación del patronato. Sin embargo, los pensadores del partido liberal empezaron a convencerse de que la separación entre la Iglesia y el Estado no era tan conveniente en la práctica como se proponía en la teoría política liberal.

Aunado a lo anterior, el periódico El Liberal, en 1853, consignaba lo siguiente: "los abusos de los prelados eclesiásticos en la imposición de sus propias contribuciones y de los curas en su cobro, que hacen temer a muchos que la libertad religiosa y en materia de contribuciones religiosas pueda causar el gravísimo mal de que los pueblos ignorantes sean explotados a mansalva por los párrocos codiciosos" (González, 1997b, p. 162 y 163), lo que condujo a que la separación entre Iglesia y Estado no durara tanto, sino hasta 1855, con la presidencia del conservador Manuel María Mallarino.

Bajo el Olimpo Radical (1863-1886), la religión católica sufrió un gran golpe, su separación del Estado, lo que ocasionó que fuese desposeída de cualquier autoridad política y jurídica. Empero, en el interior del partido liberal se presentaban dos facciones: los liberales del sector draconiano-mosquerista, que se mostraban partidarios del control de la Iglesia por el gobierno, mediante la tuición, la cual tiene las siguientes exigencias mínimas: “1) el juramento de obediencia de los clérigos a la constitución, las leyes y a las autoridades civiles, bajo pena de destierro; 2) la incapacidad de los ministros para elegir y ser elegidos y 3) amnistía general para los clérigos", (González, 1997b, p. 180 y 181), donde se muestra una clara instrumentalización de la religión a manos del Estado como método para obtener la cohesión social del pueblo y medio para desposeer al partido conservador de dicho privilegio.

Por otra parte, se presentaba la facción de los liberales radicales, los cuales propugnaban por una separación real y efectiva entre estas dos entidades, teniendo como consigna: "una iglesia libre dentro de un Estado libre". Esta época de la historia política colombiana coincidió con la pérdida del poder de la Santa Sede en Italia concentrándose principalmente en Roma y, obviamente, este fenómeno se ve reflejado en la política internacional del Vaticano. 
Cuando el presidente Mosquera expulsa al arzobispo Arbeláez en su segundo periodo presidencial en 1866, por violar la ley de inspección de cultos, se generó un nuevo descontento entre los miembros de la Iglesia. Por tal razón, también ocurre una división interna del clero nacional, pues un sector del clero apoya la moción de que la Iglesia no debe tomar parte en la política del país, sino dedicarse a la instrucción moral del pueblo, y otro sector quería ser parte de la política colombiana mediante la alianza con el partido conservador, como medio por el cual puedan restablecer su posición política, social y económica.

Con el regreso al país del arzobispo Arbeláez, tras el derrocamiento del Presidente Mosquera en 1867, se iniciaron conciliaciones con los gobiernos de Salgar (1870), Murillo (1872) y Parra (1876). Lo anterior ocasionó el descontento de la mayoría de eclesiásticos y de los militantes conservadores Miguel Antonio Caro y José Manuel Groot que, para dicho periodo, eran los directores del periódico El Tradicionista, a través del cual censuraban las actuaciones del gobierno, especialmente en el tema de la educación oficial de tipo laical.

Aquellos clérigos que no estaban de acuerdo con la postura reconciliadora y tolerante de Arbeláez, lo acusaron ante el Vaticano. Además, los obispos contrarios a Arbeláez "violaban sistemáticamente el secreto de las deliberaciones conciliares. El vicario de la misma arquidiócesis de Bogotá, padre Severo García, que supuestamente representaba al obispo de Cartagena, se comunicaba con Miguel Antonio Caro y José Groot, que se mantenían informados al detalle de todo lo que allí se discutía". (González, 1997b, p. 220)

Los liberales radicales, cuando alcanzaron el poder, se olvidaron del sufragio universal y "No cabe duda, pues, de que uno de los motivos de la limitación del sufragio fue el de facilitar cierto manipuleo discreto del proceso electoral, sin tener que recurrir a medidas extremas. O sea que deshabilitando en masa a los campesinos analfabetas, tan fácilmente engañados por los curas godos -por ejemplo- el problema político ya era mucho más sencillo de resolver" (González, 1997a, p. 124).

La confrontación sucedida en el interior del clero terminó con la muerte natural del arzobispo Arbeláez en 1884, quien hasta en su último momento defendió la idea de la no injerencia política de la Iglesia en el Estado. Por tanto, la inestabilidad política y económica del Estado federal con la descentralización de la guerra en todo el territorio nacional, "se tradujo en la inestabilidad y anarquía de los gobiernos locales, cuya transición se hizo siempre con base en los golpes de Estado" (González, 1997a, p. 129).

Como consecuencia de ello, en el gobierno del presidente Rafael Núñez se implantó una serie de reformas tendientes a la centralización del poder, lo cual se vio expresado 
en la Constitución de 1886, donde se unificó la legislación civil, penal, electoral, comercial, de minas, de organización y procedimientos judiciales y la organización independiente del poder electoral. Este acuerdo fue casi unánimemente aprobado por las municipalidades de la República.

Durante la hegemonía conservadora que siguió al gobierno de la Regeneración, se utilizó como estrategia electoral la aplicación arbitraria del requisito del alfabetismo, lo que permitía una estable administración basándose en "la presunción de que todo buen conservador sabía leer y escribir a no ser que se comprobara claramente lo contrario; y con los liberales, viceversa (...) Otro de los mecanismos electorales del conservatismo fue el apoyo clerical y jerárquico, especialmente notorio en las elecciones de Marco Fidel Suarez, Miguel Abadía Méndez y en la división conservadora de 1930" (González, 1997a, p. 130 y 131).

Todo lo anterior estaba legitimado con la expedición de la Constitución de 1886, en la cual la República colombiana se definió como un Estado confesional. Como muestra de ello en su preámbulo invoca a Dios como fuente suprema de toda autoridad y establece a la religión católica como religión oficial de la Nación, lo cual sería posteriormente ratificado por el artículo 53 que prescribía la libertad de cultos y de conciencia, siempre y cuando no estuvieran en contra de la moral cristiana y de las leyes, exime de impuestos a los templos católicos, seminarios conciliares y casas episcopales y curales (art. 55), declara la compatibilidad de los sacerdotes en cargos públicos solamente en aquellos relacionados con la educación (art. 54). Lo que permite afirmar que durante la vigencia de la Constitución de 1886, la Iglesia católica tenía un poder político con pocas limitaciones en lo que tiene que ver con el quehacer del Estado.

El gobierno colombiano derogó la ley de inspección de cultos (tuición), lo que permitió que la relación entre Estado-Iglesia se fortaleciera por medio del Concordato de 1887, ratificado por la ley 35 de 1888, donde el Estado colombiano le reconoció personería jurídica a la Iglesia, la cual podía tener bajo su potestad la educación y así mantener su hegemonía al enseñar la religión católica en las distintas instituciones educativas, podía llevar lo relacionado con el estado civil de las personas, pero de aquellas que profesaban la fe católica, como bautismos, matrimonios católicos y defunciones hasta antes de la expedición de la ley 92 de 1938.

Esto llevó a acentuar la tendencia de "la iglesia a alienarse más decididamente con el partido Conservador, que a su vez condujo a algunos conservadores a considerarse como defensores y casi dueños de la institución eclesial, a la que usaban como mecanismo electoral y movilización partidista” (González, 1997b, p. 260). Un ejemplo de ello, lo puede brindar el obispo de Pasto, Ezequiel Moreno, beatificado por el papa Pablo VI y canonizado más tarde por el papa Juan Pablo II, quien, en 
sus pastorales durante la Guerra de Los Mil Días calificaba a nuestras guerras civiles como guerras de religión.

La rebelión liberal contra el gobierno conservador no es sino un episodio de la guerra que la revolución hace a la Iglesia. En su pastoral de cuaresma de 1898, Moreno quiso demostrar que los pueblos e individuos, "contagiados por la peste del liberalismo, son castigados por Dios con el más completo abandono en el orden religioso, moral y político". Por eso, los pueblos cristianos, que saben de lo que se trata, se presentan a pedir las armas, "y dispuestos a derramar su sangre en la defensa de la religión”. (González, 1997b, p. 261)

Cabe mencionar que no solo el obispo Moreno apoyaba a los conservadores de forma verbal sino también auspiciaba la guerra dando dinero al partido conservador con una cuenta aproximada de 11.000 pesos. No obstante, hay que aclarar que no todos los clérigos estaban de acuerdo con estas actuaciones, ni tampoco algunos de los líderes del partido conservador. El conservatismo histórico (facción política del partido conservador tradicional), uno de cuyos líderes fue Carlos Martínez Silva, denunciaba la instrumentalización de la religión que realizaba Miguel Antonio Caro en su gobierno, e invitaba a la convivencia entre los partidos tradicionales y la superación de la religión como punto divisorio entre los dos partidos.

La guerra bipartidista que caracterizó a Colombia en el XIX se ve plasmada en una frase de Rafael Uribe Uribe: "la sola enunciación del tema que habrá de ser materia de este trabajo [De cómo el liberalismo político no es pecado] podría hacer sonreír en otro país que no fuese Colombia, pero aquí sabemos que no se trata de una disertación teórica sino de la cosa más seria del mundo" (Uribe, 1992), la cual refleja la realidad política del país en ese lapso.

Después de la caída de la hegemonía conservadora con la llegada al poder de Enrique Olaya Herrera (1930), el cual fue ayudado por protestantes norteamericanos y por la logia masónica, se empezó a promover una serie de propuestas que buscaban instaurar la libertad religiosa absoluta, derogar la parte del preámbulo de la Constitución donde invoca a Dios como fuente suprema de toda autoridad y la laicización de la educación. Estas propuestas de reforma encuentran, como era de esperarse, contradictores, uno de ellos fue el monseñor Builes, quien expresaba: "las reformas propuestas que son una campaña contra Dios y la Iglesia que busca la separación entre la Iglesia y el Estado, el matrimonio civil y el divorcio vincular, la soberanía popular como origen de la autoridad, la libertad absoluta de religión y de culto, la enseñanza laica y obligatoria (...) y la labor disociadora del comunismo y del socialismo" (González, 1997b, p. 286).

La Iglesia católica no solo tenía confrontaciones con el partido liberal, sino también 
con el partido socialista revolucionario, PSR, y el partido comunista, CP, los cuales habían surgido en 1930 con ocasión de la masacre de las bananeras, con gran acogida en los primeros sindicatos creados en la presidencia de Olaya. Todos juntos eran calificados por el clero como enemigos de Cristo: soldados del marxismo que provocan huelgas para corromper a las masas y arrebatarles su espíritu cristiano. Dicha confrontación se produjo debido a que la situación fáctica nacional estaba cambiando, desfavoreciendo los intereses del clero, perdiendo su monopolio cultural, político y económico, ya que como se vio antes, la Iglesia siempre ha legitimado mediante la predicación de su evangelio el régimen de clases que se ha manejado desde la colonización española con el fin de proteger sus intereses, no reconociendo los derechos de las personas que no están de acuerdo con sus postulados.

Aunque la Iglesia promovió algunas asociaciones sindicales como la JOC (Juventud Obrera Católica), fundada en 1932 y reconocida oficialmente en 1933 por el episcopado. La JOC se presentó inicialmente como una organización anticomunista y de raigambre campesina,

compitiendo exitosamente con el liberalismo en el terreno sindical, lo que despertaba los ataques de la prensa liberal lo mismo que de algunos políticos de ese partido (...), [sin embargo], monseñor Juan Manuel González Arbeláez, (...) logra que el cardenal Pizzarro desautorice desde Roma a la JOC y ordene su liquidación en 1936: al no haber suficientes sacerdotes preparados para ser consiliarios de la organización, es mejor que no haya organización obrera para evitar que los jóvenes obreros sean fácilmente seducidos por el comunismo (González, 1997b, p. 290, 291).

En 1942, el Estado colombiano y la Iglesia católica habían firmado otro concordato, pero este no fue ratificado por el Congreso. Empero, en 1973 hubo un tercer concordato entre la Iglesia y el Estado, que actualmente rige en Colombia, ratificado por la ley 20 de 1974, donde el Congreso reconoce personería jurídica a la Iglesia, otorga competencia para celebrar matrimonios conforme al credo católico, dándole efectos jurídicos a los fallos proferidos por los tribunales eclesiásticos en materia de disolución del matrimonio.

Luego de las elecciones presidenciales de 1945, donde el partido conservador ganó la presidencia con Mariano Ospina Pérez, la Iglesia entró nuevamente a ser parte del Estado en materia educativa, tanto así que expresaba que "nadie debe extrañar que imperen en la escuela la moral cristiana y las orientaciones que emanan de la fe de nuestros mayores siendo unánimemente católica" (González, 1997b, p. 294). Por ende, el gobierno conservador empezó a despedir a docentes y rectores liberales y masones y el clero retomó su posición, adquiriendo el monopolio educativo. 
La tradicional alianza entre la Iglesia y el partido conservador, tras las movilizaciones por las acciones del gobierno, estaba preparando el terreno para el periodo conocido como "la violencia", en donde se tuvo la primera manifestación violenta con la muerte de Gaitán. El "bogotazo" se convirtió en la ocasión en la cual sus seguidores quemaron templos, colegios y asesinaron sacerdotes expresando su resentimiento frente al gobierno e Iglesia, como culpables de la muerte del caudillo y dieron muestras del conocimiento que tenían respecto a la identidad entre Iglesia y Estado.

No obstante, algunos obispos, como el futuro cardenal Crisanto Luque, Gerardo Martínez y monseñor Builes imputaban los hechos ocurridos el 9 de abril de 1948 al gaitanismo como aliado del comunismo, expresando este último que "el verdadero autor de la hecatombe es el liberalismo vestido de comunismo (...). En 1949, los obispos exhortan a no votar en las próximas elecciones por el comunismo responsable del 9 de abril" (González, 1997b, p. 297). Aquí se puede observar el protagonismo de la illesia en la política, desprestigiando al partido liberal y a los partidos de izquierda que en ese momento estaban adquiriendo legitimidad, con el objeto de defender los intereses del gobierno conservador, los cuales eran los mismos, impidiendo que hubiera otros partidos políticos distintos del conservador y el liberal, con el fin de mantener el régimen político imperante, excluyente de las masas populares inconformes con el sistema vigente.

Cuando ocurrió la "dictadura" del general Rojas Pinilla, quien dio golpe de Estado al presidente interino Roberto Urdaneta Arbeláez (que sustituía a Laureano Gómez desde 1951) en el año de 1953, Rojas Pinilla fue ayudado en principio por la Iglesia católica, que vio este suceso como posible solución a la violencia que se estaba propagando por todo el país, lo que provocó el enojo de Gómez frente al clero, ya que él se había considerado como máximo defensor del mismo.

En una entrevista realizada a Rojas Pinilla, que sólo fue publicada después de su muerte, confesó que el cardenal Luque -quien era gran fanático de las políticas de Ospina Pérez- trató de "imponerle que su gabinete fuera homogéneamente ospinista" (González, 1997b, p. 298). Sin embargo, la Iglesia apoyó abiertamente el movimiento bipartidista contra Rojas, y el cardenal Luque calificó de "ilegal" la reelección del general para el periodo 1958-1962. Como consecuencia de estos ataques, "el dictador" tuvo que renunciar y dejar una junta militar para convocar plebiscito en 1957. La confrontación entre el gobierno de facto y la Iglesia trajo como consecuencia inmediata el acercamiento de la jerarquía con el partido liberal en el Frente Nacional.

Esta experiencia de "la violencia" permite comprender el acuerdo entre los dos partidos para ponerle fin mediante el reparto del poder entre ellos. (...). Este arreglo [Frente Nacional] constituyó la solución de los conflictos políticos que habían 
caracterizado la vida partidista de Colombia durante todo el siglo XIX y primera mitad del XX (González, 1997a, p. 64).

El acuerdo bipartidista dio lugar a que la Iglesia católica perdiera protagonismo político después de la segunda mitad del siglo XX, ya que, como se ha expuesto en este artículo, la burocracia eclesiástica estaba diseñada para combatir la ideología y gobiernos del partido liberal, y estaba acostumbrada a tener una estrecha relación con el Estado, especialmente cuando los gobiernos eran conservadores.

La configuración interna de la Iglesia colombiana con ocasión del Frente Nacional -tal como lo menciona el politólogo norteamericano Alexander Wilde- las estructuras eclesiásticas estaban hechas para la defensa del partido liberal laico y secular, pero no para una presencia creativa en la sociedad, la cual estaba acostumbrada a funcionar en la sociedad colombiana ejerciendo control desde arriba de las instituciones civiles consideradas como iguales o inferiores al poder clerical. Esto coincidió con la decisión tomada por el papa en el Concilio Vaticano II, "al subrayar la dimensión histórica de la Iglesia como pueblo de Dios en marcha a través de los avatares de la historia lo mismo que la concepción de la libertad religiosa".

Como consecuencia de lo anterior, la Iglesia fue perdiendo terreno dando lugar al pluralismo religioso. Este efecto fue coadyuvado por el crecimiento de las ciudades, la profesionalización de la clase media y el nuevo rol que desde el plebiscito de 1957 adquiere la mujer en la vida política, social y familiar, y la nueva interpretación que realiza el padre Camilo Torres sobre el cristianismo, creando su propia doctrina: la teología de la liberación, la cual será el fundamento ideológico de algunos grupos guerrilleros.

Con la Constitución de 1991, que en su primer artículo consagra el principio de la dignidad humana como rector del ordenamiento jurídico y en consecuencia de ello, en dicho artículo establece también el reconocimiento a la pluralidad tanto étnica, política, religiosa, cultural etc. A diferencia de la anterior constitución, la de 1991 consagra la libertad de conciencia (art. 18) y la libertad de cultos (art. 19) sin ninguna restricción al respecto, estableciendo que "Todas las confesiones religiosas e iglesias son igualmente libres ante la ley" (art. 19 inc. final).

Sin embargo, consideramos que al Estado colombiano no se le puede llamar un Estado laico ni mucho menos secular, aunque no establece una religión en especial como oficial del Estado, da ciertas prerrogativas a unas religiones e iglesias, que las ubica en posición de superioridad respecto de otras confesiones. Esto lo podemos evidenciar en la ley 20 de 1974, ley aprobatoria del Concordato de 1973 donde el Estado le reconoce personería jurídica a la Iglesia católica y además, le otorga 
competencia a los tribunales eclesiásticos para disolver matrimonios católicos por divorcio o declarar la nulidad del mismo.

Cabe mencionar también la ley 133 de 1994, ley estatutaria de libertad de cultos y conciencia, que en su artículo $3^{\circ}$ establece la igualdad de las religiones ante la ley, pero en el artículo 12 le da competencia al Ministerio del Interior para otorgar personería jurídica a aquellas religiones que cumplan con ciertos requisitos, para que puedan ser sujetos de derechos y tener la potestad de celebrar matrimonios y de decretar nulidad o divorcio con plenos efectos civiles. El decreto 354 de 1998 dio dicha posibilidad solamente a iglesias cristianas no católicas, sin aludir siquiera a otra religión distinta del cristianismo, lo que, a nuestro juicio, vulnera el derecho a la igualdad dando lugar a una ostensible discriminación hacia aquellas personas creyentes de religiones diferentes del cristianismo, al no brindar los mismos privilegios.

Por lo anterior, consideramos que el Estado colombiano es un Estado interconfesional y por tanto no es un Estado laico, porque "Para que un sistema sea realmente laico es necesario, no sólo que se declare neutral o por lo menos imparcial, frente a las confesiones o prácticas religiosas, sino, que, no le reconozca competencia a las autoridades religiosas" (Mantilla, 1998, p. 24).

No solamente por eso el Estado colombiano no se puede denominar Estado laico, porque para dar tal afirmación se requiere que se cumplan con ciertos requisitos:

1. las confesiones reconozcan que la diferenciación religiosas y la configuración de religiosidades son expresiones culturales, por lo tanto, creaciones humanas diversas; 2. Los Estados entiendan que el pluralismo radica en adecuar la conducción política a las fuerzas estructurales del cambio y de la interacción objetiva, para delegar con ello la construcción histórica del orden a los ciudadanos concretos; (cursivas fuera de texto) y 3. Los individuos sepan distinguir en el pensamiento y activar de la acción política (....). (Vladimir, 2002a, p. 54).

Según lo expresado en este artículo, ni la sociedad ni el Estado como organismo político, se encuentran en condiciones para cumplir con el paradigma de Estado laico, aunque hay que admitir que se ha avanzado no poco respecto al reconocimiento de la diversidad étnica, cultural, ideológica, política en el interior del país.

Tal avance fue consecuencia mediata del Frente Nacional, en donde (como se ha dicho reiteradas veces) la Iglesia católica perdió terreno en materia política, porque al darse el acuerdo bipartidista, la Iglesia quedó dentro del arreglo, lo que le ocasionó la pérdida del monopolio religioso que siempre la identificaba con el 
partido conservador, confrontando, como es obvio, al partido liberal; teniendo así una participación política relevante, la cual se reflejaba en la legitimidad que tenía en las clases baja y media analfabetas. Sin embargo, cuando llegó el infortunado momento tanto para el clero católico como para la democracia colombiana, aquella no se encontraba en capacidad de asumir el fenómeno plurirreligioso que se empezaba a mostrar con la intromisión de otras iglesias en el territorio colombiano.

Lo anterior lo describe Gabriel Pabón Villamizar, dando a entender que el surgimiento e "importación" de iglesias cristianas al territorio colombiano para buscar adeptos, luego obtener riqueza de forma rápida y fácil como consecuencia de la manipulación de sus devotos al dar ofrendas y diezmos "en bien de la iglesia y para obtener la bendición de Dios" en sus quehaceres cotidianos y necesidades tanto materiales como espirituales. Por tanto, "El reconocimiento de libertades religiosas está más allá de las relaciones entre Estados y confesiones; devotos pueden significar votos, creyentes mercados. La diferenciación confesional y las trashumancias devocionales han complejizado el panorama de la diversidad religiosa, con lo cual los viejos referentes tienden a inutilizarse, requiriendo necesariamente la revisión histórica. La falta de compresión de este hecho, perfila resistencias al pluralismo" (Vladimir, 2002, p. 58).

Iglesias como Centro Misionero Bethesda, Oración Fuerte al Espíritu Santo, Casa sobre la Roca, Avivamiento Centro para las Naciones, Jesucristo Internacional, Misión Carismática (G 12) etc., comparten frases comunes, como "Hay que ofrendar, y especialmente aportar diezmos, (...) cuando invertimos en los proyectos de Dios, Dios va a invertir en los proyectos de nosotros" (Pabón, 2011, p. 14 y ss), entre otras oraciones. Siempre convergen en el mismo fin: obtener capital por medio de la manipulación de las conciencias de las gentes y simultáneamente servir de base para la configuración política de la iglesia, la cual se verá representada en los más altos escaños de la política nacional.

Un ejemplo de ello, lo puede ofrecer la iglesia del G 12, en la cual, la misión para sus adeptos era imponerse la formación de células de doce. En tres años (1991 a 1994), la Iglesia subió de setenta a mil doscientos feligreses, y en los cinco años siguientes se multiplicaron las adhesiones, de tal manera que se alcanzó pronto la cifra de cuarenta y cinco mil asistentes semanales al templo. Pero,

La multiplicación de la iglesia no es gratuita. Aplicando los principios del capitalismo salvaje y de las megaempresas, Castellanos [pastor fundador del G12] cobra ciento veinte mil pesos por franquicia (...). Este capital social se traduce en un inmenso caudal político. Para las elecciones en que salió elegido Álvaro Uribe nunca se sabrá con precisión cuál fue el aporte exacto para su triunfo, pero lo cierto es que es determinante. (...). A raíz de la reforma 
política, el Partido Nacional Cristiano [partido político creado por G 12] se esfumó, y los Castellanos optaron por engrosar las listas uribistas de Cambio Radical” (Pabón, 2011, p. 36-39)

En esta cita se ve la estrecha relación entre religión, economía y política, en donde la primera propicia los medios para acumular capital y después, como este es invertido en la política como fórmula de ascenso de estos personajes, que, por lo general, son gente de clases sociales excluidas que quieren llegar a ser parte de la oligarquía colombiana.

Otro ejemplo lo puede dar el movimiento político MIRA “Movimiento Independiente de Renovación Absoluta (internamente también significa Movimiento Imitador de la Rectitud del Altísimo) (...) En cuanto a la Renovación Absoluta, cabe decir que el partido tiene de renovación poco, y de absolutismo mucho. La cercanía entre la prédica religiosa y el verticalismo político absolutista se pone de manifiesto en el discurso proselitista de sus dirigentes" (Pabón, 2011, p. 54 y 55)

Sin embargo, con la creación de la Corte Constitucional como máximo órgano colegiado intérprete de la Constitución, en materia indígena ha avanzado en garantizar la pluralidad, la convivencia pacífica, la interculturalidad, la igualdad de la diversidad de concepciones del mundo, y la no imposición de una concepción particular del mundo. Ello se puede demostrar en la sentencia de unificación SU- 510 de 1998, en donde garantiza el derecho a la pluralidad religiosa al pueblo indígena Yanacona mediante el reconocimiento a la diversidad étnica y cultural.

Los hechos de la sentencia versan sobre la intromisión que estaba haciendo la IPUC (Iglesia Pentecostés Unida de Colombia) en el cabildo indígena Yanacona de Caquiona (CYC), llevando sus predicas en esta comunidad sin permiso de las autoridades indígenas, abusando de su derecho de libertad religiosa colocando amplificadores y obligando a escuchar sus prédicas a los miembros de la comunidad aborigen que no estaban de acuerdo con esta conducta.

La IPUC presenta recurso de revisión con el argumento de que se le está vulnerando el derecho a la libertad de cultos y conciencia expresando que ellos pueden predicar su evangelio en cualquier lugar en el territorio nacional. Entonces la Corte Constitucional contesta arguyendo que:

"Se equivoca la IPUC al trivializar el conflicto suscitado con las autoridades del Cabildo indígena de Caquiona reduciendo el enfrentamiento entre religión católica y la religión protestante (...), a) No se trata solamente del enfrentamiento religioso, sino de las persecuciones que tal contienda frente a la organización social, política y económica de la comunidad, toda vez que, 
los Indígenas que se han afiliado a la IPUC se oponen al modo de producción comunitaria y a las obligaciones de vigilancia, al propio tiempo que desconocen las tradiciones ancestrales; b) se violan derechos de los demás miembros de la comunidad al obligarlos a escuchar el culto protestante mediante amplificadores y se desafía las decisiones tomadas por la autoridad tradicional, luego de agotado un proceso. (Sent. SU 510, 1998)

La Corte hace una relación entre el principio de pluralidad religiosa y el principio de diversidad étnica y cultural, con las siguientes palabras: "en esta tarea (confesionalidad), además le está vedado imponer una concepción del mundo particular, así la vea como valiosa, porque tal actitud atentaría contra el principio de respeto a la diversidad étnica y cultural y contra el trato igualitario para las diferentes culturas que ha reconocido" (Sent. SU 510, 1998). En la sentencia T641/99, la Corte establece el núcleo esencial de la libertad de cultos (confesionalidad), el cual se traduce en la posibilidad de ejercer el culto sin vulnerar el ordenamiento jurídico y el derecho de las demás culturas o personas.

Hay que mencionar que la religión está compuesta de dos factores: "La cosmovisión implica un orden del mundo, es un concepto relacional con lo extrínseco al ser humano, mientras que la confesión, en tanto expresión de la conciencia, es una relación del alma consigo misma, una relación intrínseca del ser, un estado interior que permite juzgar a sí mismo" (Vladimir, 2002b, p. 209); por lo tanto, la segunda adquiere un acento más político que religioso con características fundamentalistas con tendencias de universalidad, mientras que la primera es aceptada como un fenómeno cultural e histórico, la cual, está sujeta al establecimiento de una sociedad en particular. Esta perspectiva es la que permite la tolerancia y respeto hacia otros cultos.

La religión popular católica practicada por los indígenas Yanaconas es de tipo "cosmovisional", debido a la configuración histórica que la mencionada comunidad aborigen tomó desde sus primeros integrantes y porque se basa en una relación del ser con el universo, la cual erige las estructuras política, social, económica y cultural de la comunidad.

\section{Conclusiones}

1. La religión, especialmente la católica, ha estado presente en toda la historia política del país y por tanto, no es aceptable que se hable de la historia colombiana prescindiendo del papel de la religión en la política, ya que no solo es capaz de dominar a un pueblo sino también de provocar enfrentamientos y revoluciones en contra del régimen presente.

2. Cabe mencionar que en la historia política colombiana, la iglesia católica ha sido muy conveniente apoyando a personas o partidos políticos que defienden sus 
causas sin importar que esto conlleve a romper con sus postulados axiológicos con tal de conseguir sus objetivos, legitimando no solo el régimen político establecido desde la colonización española, sino también durante la constante guerra bipartidista común del siglo XIX y primera mitad del siglo XX.

3. La iglesia católica, hasta el Frente Nacional, fue una gran protagonista en la arena política del país, no solo debido a su poder religioso con el que mantenía sumiso a gran parte de la sociedad colombiana, sino también a su gran poder económico y monopolio educativo que ostentaba desde la colonia, siendo el primer ente que tuvo como objeto el establecimiento de la educación en la época de la colonización y la institución que tenía el pleno control de la educación en los gobiernos conservadores, impidiendo el ingreso al territorio de obras e ideas que fueran contrarias a sus propósitos, obstaculizando la implementación de esas nuevas ideas, impidiendo la formación de una cultura política en la población y la consolidación de nuevos partidos distintos del conservador y liberal.

4. Después del Frente Nacional, la Iglesia fue perdiendo poder político debido al acuerdo bipartidista, el clero entró a gobernar indistintamente con el partido liberal y conservador, y esto trajo como consecuencia la pérdida de la identidad tradicional que tenía respecto del partido conservador, lo cual llevó a un proceso de pluralidad religiosa y a la disminución de la legitimidad que ostentaba antes de este suceso.

5. Desde nuestro punto de vista, tanto la Iglesia católica como las iglesias cristianas no católicas, han tenido gran participación política en el Estado debido a la capacidad económica que cada una de ellas detenta para financiar campañas políticas (caso G 12-Uribe Vélez) o la financiación de guerras por parte de algunos cleros, al partido conservador (Guerra de los Supremos), lo cual lleva a inferir que para que no se presenten estas situaciones, será menester establecer una serie de limitaciones a estas instituciones para que no puedan tener patrimonio, como condición previa para establecer la no injerencia de religión en política.

6. Como medida para establecer la separación religión y política, es necesario la consolidación de una democracia participativa donde cada una de las personas goce de una culturización política, que cada uno de nosotros pueda tener un pensamiento crítico frente a lo establecido, para que dejemos de ser instrumentos o medios de aquellas personas que valiéndose de dogmas religiosos o políticos, pretendan llegar al poder para seguir manteniendo el régimen político existente. Lo anterior sólo se puede lograr mediante la instauración de un sistema educativo que permita el aprendizaje de la religión desde una perspectiva histórica, mas no fundamentalista, como actualmente está establecido.

7. Para que se pueda hablar de pluralismo religioso es imprescindible que se entienda que cada religión es una manifestación cultural, que depende de la sociedad donde se es aplicable, es decir, que se piense en la religión en una cosmovisión y no una confesión como fórmula para abolir los fundamentalismos y dar pie al reconocimiento de la diversidad cultural, étnica, política etc. 
8. Por consiguiente, el Estado colombiano no puede denominarse Estado laico o secular, porque como lo vimos más arriba, el Estado otorga ciertas prerrogativas a contados cultos, poniendo en situación de desigualdad a aquellas religiones que no ostentan esta calidad. Por tanto, el Estado colombiano es fundamentalmente un Estado interconfesional, aunque tiene como premisa mayor el reconocimiento a la pluralidad.

\section{Lista de Referencias}

Constitución Política de 1886.

Corte Constitucional. (1998). Sentencia SU 510.

Decreto 354 de 1998.

Galeano, E. (1970). Venas abiertas de América Latina. Bogotá: Círculo de Lectores.

González, F. (1997a). Para leer la política. Bogotá: Antropos.

González, F. (1997b). Poderes enfrentados. Iglesia y Estado en Colombia. Bogotá: Antropos.

Legis. (2013). Constitución Política de 1991. Bogotá: Legis.

Ley 20 de 1974.

Ley 133 de 1994.

Mantilla, R. (1998). Conflictos interconfesionales familia, religión y Estado. Bogotá: Universidad Nacional de Colombia, Facultad de Derecho, Ciencias Políticas y Sociales.

Pabón, G. (2011). En el nombre del Señor. El negocio de la religión. Bogotá: Debate.

Uribe, C. (1992). La mentalidad del colombiano. Cultura y sociedad en el siglo $X X$. Bogotá: Alborada.

Vladimir, C. (2002a). Confesionalidad y política. Confrontaciones multiculturales por el monopolio religioso. Bogotá: Universidad Nacional de Colombia, Facultad de Derecho, Ciencias Políticas y Sociales.

Vladimir, C. (2002b). Pluralismo religioso y libertad de conciencia. Configuraciones jurídicas y políticas en la contemporaneidad. Bogotá: Universidad Nacional de Colombia, Facultad de Derecho, Ciencias Políticas y Sociales. 